This page intentionally left blank 


\title{
Extending the Frontiers
}

\author{
Essays on the New Transatlantic
}

Slave Trade Database

Edited by David Eltis and David Richardson

Yale University Press

New Haven \& London 
Published with assistance from the Annie Burr Lewis Fund and from the foundation established in memory of Philip Hamilton McMillan of the Class of I894, Yale College.

Copyright (C) 2008 by Yale University.

All rights reserved.

This book may not be reproduced, in whole or in part, including illustrations, in any form (beyond that copying permitted by Sections I07 and 108 of the U.S. Copyright Law and except by reviewers for the public press), without written permission from the publishers.

Set in Adobe Garamond and Stone Sans by Binghamton Valley Composition.

Printed in the United States of America by Thomson Shore.

\section{Library of Congress Cataloging-in-Publication Data}

Extending the frontiers : essays on the new transatlantic slave trade database / edited by David Eltis and David Richardson.

p. $\mathrm{cm}$.

Includes bibliographical references and index.

ISBN 978-0-300-I3436-o (cloth : alk. paper) I. Slave trade-AfricaHistory-Sources. 2. Slave trade-Africa-History-Statistics. 3. Slave trade-Portugal-History—Sources. 4. Slave trade-Brazil-History-Sources. 5. Slave trade-Central America-History-Sources. 6. Slave trade-EuropeHistory—Sources. 7. Slave trade-America-History—Sources. I. Eltis, David, I940- II. Richardson, David, I946- III. Title: Essays on the new transatlantic slave trade database. IV. Title: Essays on the new trans-Atlantic slave trade database. V. Title: Trans-Atlantic slave trade

$$
\begin{aligned}
& \text { HTi32I.E98 } 2008 \\
& 306.3^{\prime} 62-\mathrm{dc22}
\end{aligned}
$$

A catalogue record for this book is available from the British Library.

The paper in this book meets the guidelines for permanence and durability of the Committee on Production Guidelines for Book Longevity of the Council on Library Resources. 
To Paul Lachance 
This page intentionally left blank 